\title{
Why do SONGS haVe WoRdS IN DIFFERENT LANGUAges? Negotiating MinORITY IDENTITY THROUGH LANGUAGE CHOICE AMONG SWEDISH-SPEAKING MUSICIANS IN FINLAND
}

\section{Johannes Brusila}

The main heading of this article is a paraphrase of the title of Simon Frith's seminal essay »Why Do Songs Have Words?« (1987), which, in my opinion, remains a neat critical summary of the various traditions of studying song lyrics. Since then, the study of music and lyrics has developed further in various directions, but only rarely has the choice of language been dealt with more systematically (notable exceptions being Berger/Carroll 2003). Yet, it is obvious that choosing which language to use in song lyrics is of great importance for the artists, the media and the listeners. Even the use of single phrases, code-switching, nuances in pronunciation, or dialect can signify important ethnic, social, or aesthetic positions. The choice of language also has consequences for the structure and sound of the music, its industrial dissemination and economic potential, and how it is received and understood.

The aim of this article is to ask what motivates artists themselves in the choices they make in respect of language and how these choices relate to their sociolinguistic and cultural contexts, musical framework and construction of identity. I have focused on popular musicians who belong to the Swedish-speaking population of Finland - a minority that I have studied for several years. Many members of this so-called »Finland-Swedish « minority are often capable of using different forms of Swedish, at least basic English and frequently also Finnish, which means that they make a conscious choice when they decide which language to use. As language is a key element in this minority's identity, the language of a performance is frequently discussed in the Swedish-language mass media in Finland and artists have thus often articulated opinions about their own choices. The minority position of Finland Swedish also offers an opportunity to bring to the fore many of the 
key questions brought up by sociolinguistics, music research and identity studies in this area.

\section{Music and Language}

To ask why songs have words in different languages inevitably includes complex issues surrounding the relationship between language and music, which can range from »music as/in/about language « to »language as/in/ about music « (to use the terminology of Feld/Fox 1984: 26-29). Simplistic premises regarding the meaning of words can obstruct an analysis and hinder it from arriving at a deeper understanding of the various uses of language in connection to music. When discussing the language choices within the Swedish-speaking minority of Finland I have chosen to focus on three dimensions of language and how these dimensions relate to song lyricism, as follows: language as a tool of communication, language as an aesthetic element of musical expression, and language as a constituent of social construction.

For many artists throughout the world language choice is most likely fundamentally about communication; in other words it concerns expressing yourself in a language that you know and that is understood by the audience. The question of comprehensibility and the verbal exchange of ideas consequently frame both the artists' language and their career choices. As a result of the historically recent, but nevertheless firmly established, European nation-state ideology, the issue of language is also often understood to be a choice between developing a domestic career, using the national language of the artist's home country, or an international career, using English. However, the tensions between the many variations of national languages, dialects, minority languages, regional languages and so on, imply that the comprehensibility of a language, particularly when used in sung lyrics, is often much more complex than a matter of simple semantics.

Furthermore, it is questionable to what extent any analysis that merely sticks to the level of comprehensibility can grasp the manifold levels of lyrical expression. As Frith (1987) has already revealed in his discussion of song lyrics, content analysis and theories of lyrical realism have a tendency to trivialize the musical context of the words and assert simplistic, direct relationships between a lyric and the social or emotional condition it describes and evokes. Song words undoubtedly communicate meanings and in that sense understanding the lyrics is an important aspect of the music, but a full understanding of the semantic level is not necessarily required for a lis- 
tener to enjoy the song. Following Frith we can assume that the listener can appreciate it although he or she may not know the language and even though the words may be open to numerous interpretations. In fact, the ambiguity of the lyrics can be precisely what makes the song feel personally relevant and offer people the terms in which to articulate and experience emotions.

The use of words in combination with music always incorporates an aesthetic dimension. Words can be used as a means of creating beauty or as a tool for personal creativity. In fact, it is possible to argue that the semantic level is of minor importance in popular music, or as sociolinguist Peter Trudgill (1983: 159) has stated: "pop-music is a field where language is especially socially symbolic, and typically low in communicative function, high on the phatic and self-expressive «. In aesthetic terms, a personal expression is created by combining language and music in myriad ways. This might include not only adding words to a melody but also musical speech surrogates, Sprechgesang, recitation, lamentation and a number of verbal and non-verbal devices used by the performer, such as sighs, pleas and nonsensical playing with words and syllables. Thus, the meaning of a song is not necessarily only communicated through the words used; instead, it can be argued that the language provides raw material for a whole vocal performance. A study of only the text without the "phonotext «, in other words of the interaction between words and music in the enunciation of the song, is therefore clearly inadequate (Lindberg 1995).

The choice of language and the creation of a phonotext reflect aesthetic norms, which in turn are socially, historically and culturally grounded. Often genres create an interpretative framework for our understanding of linguistic-aesthetic values. It is in relation to genre conventions that artists position their stances and listeners form their attitudes towards the music. However, as Edward Larkey (2003: 148) has pointed out, it is also worth remembering that genre may perform an ironic function, by creating interpretative expectations that are overturned as a result of unanticipated humorous connections between discrepant stylistic features.

Finally, language not only communicates semantic and aesthetic meanings; on a more general level it is a fundamental constituent of our social lives. Following social constructionist approaches it is pertinent to argue that language not only describes, but actually discursively constructs our ideas of reality (e.g. Burr 1995). For example, our self-conception and feelings of belonging and identity are lived through linguistic behaviour and often institutionalized through linguistic practices. For multilingual speakers language choice is not only an effective means of communication but also 
an act of identity; we maintain and change ethnic group boundaries and personal relationships, and construct and define »self « and »other « within a broader political economy and historical context (Wei 2000: 14f.). These processes can also lead to far-reaching language ideologies, which express people's beliefs and interests concerning the structure and use of language within social life.

The choice of language in music is always related to this socially framed linguistic context. »Musicking«, to use Small's expression (1997), includes not only song lyrics but also musicians' talk about music and even general social interactions around musical practices that do not necessarily directly discuss music. On a broader level, governmental structures, political parties, jurisdiction, the culture industry and numerous other institutions can outline, regulate, safeguard and counteract linguistic practices within the musical sphere. However, as creative artists, musicians not only follow or reproduce these structures, but also actively think about them and transform them (Harris/Carroll 2003: xiv). By choosing between and combining the linguistic practices of various social statuses, dialects and slang, musicians can publicly think about, enact and perform their identities in imaginative ways.

\section{The Swedish-Speaking Minority of Finland}

The sociocultural dimensions of language are crucial for a primarily linguistically defined ethnic grouping such as the Swedish-speaking minority of Finland (for general overviews, see e.g. Allardt/Starck 1989 and Åström et al. 2001). Swedish is the formally registered mother tongue of approximately 290,000 people in Finland, representing roughly 5.5 per cent of the total population. Despite the small size of the Swedish-speaking population, Finland is officially bilingual and according to the constitution, Swedishspeaking Finns have the right to equal levels of access to public services as does the majority population. It is of course questionable to what extent equality can be achieved in practice on all formal and informal levels of society. As a result, many Swedish-speakers feel that their linguistic position is threatened and the language ideology of the political party of Swedishspeakers in Finland, Svenska Folkpartiet, is based on the idea that monolingual institutional solutions secure bilingualism, because bilingual institutions ultimately lead to monolingual Finnish dominance.

Although legislation and political measures have offered some guarantees for Swedish governmental institutions, they have no effect on, for 
example, free market popular culture. The Swedish-speaking population is simply too small and culturally heterogeneous to viably sustain its own profitable niche in the music industry of Finland.

Despite attempts to build marketing and distribution channels for Finland-Swedish music, all enterprises have remained commercially modest and ultimately they have all been forced to shut down (Jan-Erik Lindqvist, interview 13.3.2007). Over the years, only one record company, Okay's Music, has survived, focusing entirely on releasing Finland-Swedish music. However, Okay can also be thought of more as an idealistic project than a profit-making enterprise, as its sales figures have usually amounted to around a few hundred copies per record and 1,000 copies for a successful record (Törnroos 2015). Contrary to many other small countries in Europe, the sales figures for domestic music have always been high in Finland and most of the successful music produced domestically has been performed in Finnish. This means that the music industry in Finland has traditionally tried to persuade musicians to sing in Finnish and only the artists who have aimed at an international market have used English, whereas Swedish is not seen to have any market potential at all. Generally speaking, only a few artists with a Swedish-language repertoire have had an opportunity to get a recording contract with any of the mainstream companies in Finland. Thus, it is natural that the artists who aim at a professional career performing in Swedish have moved to Sweden and tried to break through in the Swedish music industry and media.

As a primarily linguistically defined ethnicity, Finland-Swedish self-identification is constructed as a difference in relation to three major »others «: Finnish majority culture, the culture of Sweden and what might be summarized in the concept »international culture «, which, in the case of popular music is concretized in the use of the English language (Brusila 2008; Brusila 2009; Brusila forthcoming). When Finland-Swedish popular music and particularly its linguistic dimensions are explicitly debated in public, FinlandSwedishness is typically constructed in relation to these anti-poles. I have visualized this identity formation in a schematic diagram (see figure 1). The core of this Finland-Swedish self-identification positions itself in relation to the three fixed points of the outer circle; that is, its self-identification is based on a feeling of difference, or distance, from the Finnish, Swedish and international cultures. In this core, popular music is institutionalized in small-scale activities, within the home or Swedish associations and often supported by the third sector. Between the core and the outer circle is a complex, diversified border zone, where many Swedish-speaking musicians 
have operated in practice, switching between languages, musical genres and structures.

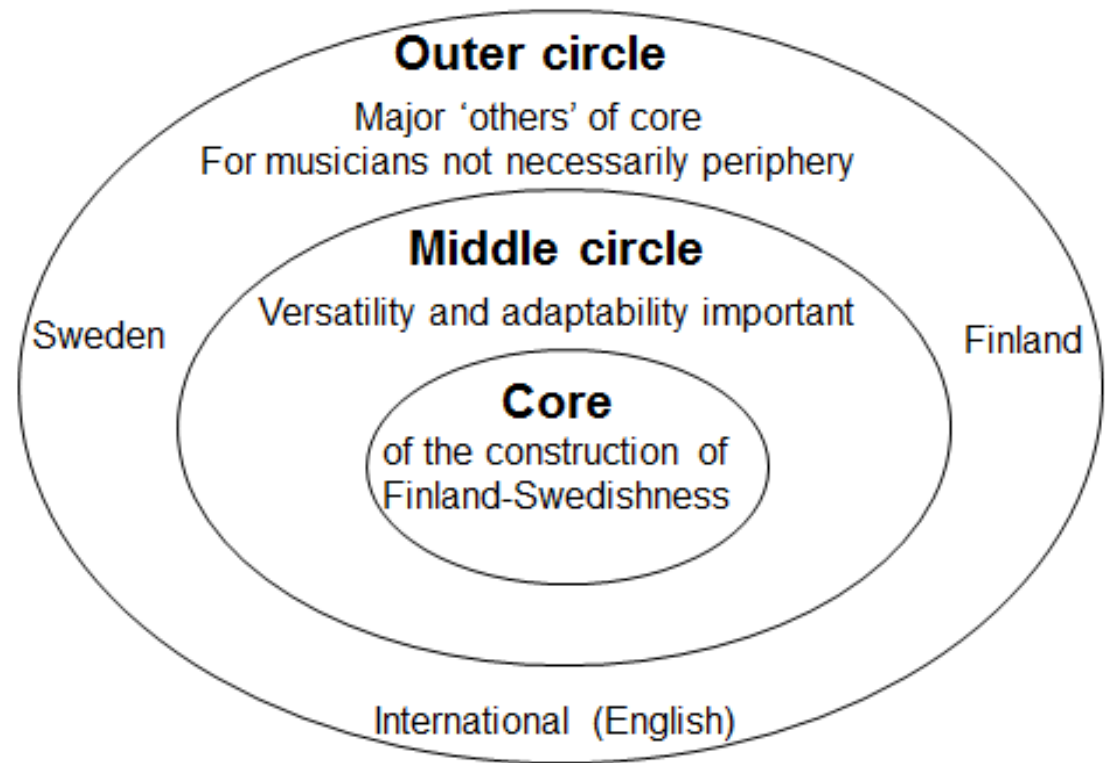

Figure 1: A schematic presentation of the discursive construction of Finland-Swedishness (ibid.). The core of Finland-Swedish self-identification is constructed in relation to the three major »others « of the outer circle. The middle circle consists of a diversified border zone where many musicians operate.

It is important to understand that this is a general description of how an ethnicity, called Finland-Swedishness, is constructed, not a description of an essence of Finland-Swedishness, or of how all Swedish-speaking individuals understand their identity. As a discursive construct (following theories of e.g. Barth 1969; Hall 1992 and 1996), this Finland-Swedish formation is processual and subject to continuous negotiations. In fact, for many Swedish-speaking musicians the outer or middle circle can form a central stage for their professional activities, working in, for example, a multilingual environment, or singing only in Finnish for a Finnish majority audience. It is the complexity of these career choices and their linguistic dimensions, which I will turn to now. 


\section{The Core: Singing in Swedish in Finland}

In Finland, as in many other European countries, the acculturation of AngloAmerican rock proceeded gradually from national schlager (in Finnish iskelmä) and copies of foreign influences in the 1950s and 1960s to the establishment of a national rock tradition sung in a local language from the beginning of the 1970s (for international comparisons see e.g. Lilliestam 1998; Larkey 2000). Although many of the key musicians and business executives in Finland who were involved in this process were Swedish speakers, popular music sung in Swedish never gained a position in the music industry because of its minimal market potential. In the $20^{\text {th }}$ century Swedish-language popular music thus became confined to small-scale contexts and formal settings.

In my schema these musical practices, in which Swedish is a key element, belong to the core of the Finland-Swedish formation. This core consists of phenomena that are more or less explicitly denominated FinlandSwedish or typically associated with some kind of Finland-Swedishness. Thus, these musical practices exist in at least a more or less permanent relation to so-called »Finland-Swedishness «, although it would be impossible to create some kind of a quantitative, demographic, geographic, or even linguistic definition of their exact degree of Finland-Swedishness. The musicking is commonly carried out in Swedish, predominantly small-scale activities in the private sphere, including for example choir singing, the Nordic singer-songwriter tradition called vissång, the variety tradition of the youth organizations, drinking songs and children's music. Partly included is the dance band music (in Swedish dansbandsmusik), which has flourished at dances organized by youth associations and other organizations, mainly in the countryside. The few rock bands who sing in Swedish or in local dialects can also be included in this core.

As a consequence of the small-scale nature of the commercial operations, the main emphasis of Swedish-language public music-making has, during the last ten to fifteen years, shifted to the so-called third sector; that is, to non-governmental foundations and associations whose explicit purpose is to promote Finland-Swedish culture. Ever since the 1980s many of these foundations have also supported popular music although, especially on the rock scene, receiving grants was for a long time seen as an embarrassing and questionable move from the perspective of an artist's credibility (Brusila 2008: 21f.). Despite the financial support for record productions, singing in Swedish in Finland has remained a fringe activity of the 
popular music market. As a consequence, rock and pop bands - such as Vasas flora och fauna - often explain that a major obstacle to starting to use Swedish has been "a huge lack of [Finland-Swedish] role models and idols« (Willows 2012).

The musicians who deliberately choose to write and perform their lyrics in Swedish usually produce their own records and release their material on the Internet. In this context the choice of language can be driven by a sense of identity, or dictated by linguistic skills. In its simplest form this can be stated in a rather laconic way as an obvious fact, as when the rock band Häxjesus succinctly explains its use of Swedish: "We did not start by thinking about the language choice; it was self-evident. Swedish is our mother tongue (Granö 2014). For others, the choice can be a language political statement, as in the case of the pop artist Niklas Rosström of Pappas eget band (interview 13.11.2009), who summarizes his standpoint of not accepting any forms of bilingual solution: »Either you speak Swedish or you don't «.

Language choice can also be the result of artistic ambitions or of a selfcritical evaluation of linguistic competence. Particularly in the region of Ostrobothnia, where there are many monolingual Swedish municipalities and most people grow up following the Swedish media, not all artists know Finnish well enough to be able to use it in their creative careers. A basic knowledge of Finnish does not necessarily mean that an artist would feel at home on the national mainstream music scene. For example, for the Finland-Swedish rapper Qruu the Finnish rap scene seems far off, even though he knows Finnish, whilst Swedish rap has intuitively been a natural framework for him: »I suppose it is because if it is in your mother tongue it somehow goes directly into your heart « (interview 4.3.2009). English feels easier than Finnish for many and would maybe offer opportunities to reach wider audiences, but on the other hand switching to English can feel like a betrayal of one's artistic ambitions without any promise of secure financial gain. In the words of Qruu: »Business-wise it would maybe be a good idea to try [to use English], but this is still first and foremost an art for me, so I don't think about it as a profession or career choice (Sandell 2011). The fact that the main incentive for making music is not necessarily commercial success gives the artist freedom to focus on self-expression and artistic autonomy, made manifest in their use of Swedish.

Choosing Swedish also involves choosing which Swedish to use. Sociolinguists divide Swedish into five standard languages, of which four are spoken in Sweden and one is the so-called Finland-Swedish standard language, as is used in, for example, the Swedish language media in Finland (Einarsson 2004: 140). Furthermore, there are several strong, local dialects in the 
Swedish-speaking regions of Finland, some of which are spoken and understood by only a few thousand people. It has been claimed that probably up to $50 \%$ of the Swedish population of Finland have a local dialect of Swedish as their only true mother tongue, this being the only language that they truly master (Loman 1983: 71). Thus, some of the artists who sing in Swedish choose to avoid standard Finland-Swedish, and instead use one of the local dialects, as this is their personal, or even only, language. This choice is often explained as being a result of the fact that the phrasing feels more natural and comfortable to sing. Apparently, the dialect structures the texts and also the sung phonotext by connecting the intonation of the language with the melody of the song. The dialect can also create an individual niche for the artist if the music otherwise resembles that of many other bands from all over the world. For example Lasse Eriksson explains that his, and his fellow artist Anders Teir's, original motivation for singing cover versions of rock evergreens with new lyrics in the Närpes dialect was a feeling that »There are so many bands that sing in English who are better than we, but what we know is the dialect « (Törnroos 2011).

In some instances the use of dialect becomes a statement, as in the case of the rock band Paradisbacka, who proclaim that: "To explain that you have to use standard Swedish is like saying that you are not worth anything if you don't follow our rules « (Hagström 2005). Sometimes artists have also been mocked for using standard Finland-Swedish, because it doesn't have sufficient credibility when singing, for example, rock songs. In such cases the language choice constructs meaning through association; it becomes an aural trigger that connects the musical expression with personality, local community, lifestyle and values.

The use of dialect in stage performances has a long tradition in the Swedish-speaking countryside of Finland, where youth associations have for several decades arranged annual comic revues performed in the local dialect. In these revues performances of sketches alternate with internationally derived evergreens with new lyrics commenting on daily life from the perspective of the local community. Partly because of this, and partly because of a general tendency to make fun of rural dialects in the modern media, dialects are usually associated with humour. As a result, most artists who use dialect sing humorous songs and even those who do not have any explicitly comic intention are often interpreted as being funny. It is worth remembering that the borderlines between dialect and sociolect are seldom very distinct, and usually the more pronounced the dialect is, the lower it is on the social scale and vice versa (Einarsson 2004: 146). A local dialect can 
signify a socially lower >otherness which is made fun of. This is something musicians need to take into consideration.

The humorous aspect can also incorporate polysemic qualities that open the songs up to different interpretations, ambiguities and encodings related to social status and belonging. Particularly for those musicians who don't want to preserve some kind of an "authentic dialect «, the creative use of dialect can be an important self-expressive tool in their artistry; it is something that offers them agency. For example the band $1 \mathrm{G} 3 \mathrm{~B}$ uses the members' strong home dialect, which is spoken by around 10,000 people living in the Närpes region, in an inventive way (Brusila 2010). A humorous effect is born out of the incongruous combination of the rural dialect, the bizarre imagery of the band's videos, and heavy metal music with distorted guitars and a drop-down tuned bass playing power chords in Aeolian, Phrygian or Locrian modes over intense drum patterns on double bass drums. The band's concept is created on the Internet, where all the material is easily accessible for free, thus recreating a local but simultaneously deterritorialized identity of Närpes on the web.

\section{Middle Circle: Alternating between Swedish, Finnish and English}

As was already mentioned, my schematic outline of Finland-Swedishness can give a false impression of this discursive formation as being something which is solid and compact. In fact, it is in the nature of cultural formations such as these that they are processual and relative. Thus, the core of the whole formation of Finland-Swedishness is in no way the core of all the heterogeneous and kaleidoscopic forms of Swedishness that exist in Finland. In order to reflect the multiplicity of how different individuals can relate to the construction of Finland-Swedishness, I have chosen to add a zone to my schema between the core and the outer circle. By doing so I want to emphasize how many people - both musicians and music industry personnel who come from the Swedish-speaking minority have always negotiated themselves a position in the national music institutions using Finnish and Swedish, and occasionally English. From this perspective it is possible to say that the history of popular music from Finland is in fact also the history of many Swedish-speaking popular musicians and entrepreneurs, who have often been the first intermediaries of international styles and influential in the creation of an acculturated national music. 
For many musicians the language barrier has not necessarily meant an insurmountable obstacle but a border to be negotiated during the development of their careers. Alternating between Swedish and Finnish can be seen as a betrayal of the Finland-Swedish language policy, which favours monolingual minority solutions, and artists also need to be aware of the risks involved when switching to another language. The use of Swedish can annoy Finnish speakers and the use of Finnish can mean that the artist loses his or her audience in the Swedish-speaking regions. Some bands can cross the language borders freely, but these are usually less well-known in the media and mainly perform, for example, at weddings and birthday parties. One such band member called his group »a piece of the scenery « or a »scenery band «; the band does not want a strong stylistic or linguistic profile, because it is hired to adjust itself to the occasion, to blend in with the background.

A number of artists pronounce Swedish in a way that resembles the standard Swedish pronunciations used in Sweden, rather than standard Finland-Swedish. Often this is a result of the influence from the artists' Swedish idols. Particularly in the Swedish regions of the Finnish west coast, musicians have traditionally followed the Swedish national broadcast TV and radio channels, which has also left its mark on their musical styles and language. The choice of pronunciation is often explained in terms of aesthetic choices; the differences between the various Swedish accents clearly have an impact on the general vocal timbre, but also phrasing and melody. However, it is also obvious that even tiny distinctions in the pronunciation of Swedish can be key signifiers of identity (which is rather ironic as most Finland-Swedish and non-Anglophone artists in general can pronounce English in basically any way without anybody taking notice of it in Finland).

The influence of the Swedish music media is often heard in the artists' singing, although they may only produce standard Finland-Swedish or a dialect when they speak. The deviations between spoken and sung accents seem to be of a particular and relatively constrained type. Thus, the artists in many ways appear to follow the same general principles that Trudgill (1983: 158f.) has noted in his study of the sociolinguistics of British pop singers' English pronunciation; the selection of linguistic forms from different codes may be due to mixed motives and a combination of different linguistic features may be very functional in retaining a balanced public and self-image. In other words, very small nuances can establish a difference between a person's musical identity and his or her other identities in a way which fulfils personal practical functions. Sometimes the singer feels that a certain pronunciation forms a natural part of his or her identity as a singer 
although his or her everyday identity in other fields of life would be enacted through another pronunciation.

Many of the artists who use different languages call themselves at least to some extent linguistically bilingual. However, as a rule, they use only one language in their music and even if they switch between languages during their careers, they will use one language at a time, for example on one record or tour. Thus, the various forms of bilingualism which can be found in everyday verbal interactions, such as language borrowing, interference or transference (see e.g. Romaine 1989: 50f.), are at least to some extent absent in the song lyrics.

The only genre where language alternation and code switching is common even within one song is hip-hop, where rappers with diverse linguistic, dialectal and slang backgrounds co-operate. Often this is explained as a natural consequence of the fact that the rappers often participate in each other's performances and recordings (as for example in the projects of Nörttibois Crew, Funkeyh \& Winnie, and Qruu). The use of one's personal verbal style in various contexts also emphasizes the importance of originality in rap. Thus, for example, Mikael »Dt1 « Hästö (Nörttibois Crew, interview 15.12.2008) explains how he wants to accentuate his personal voice: "No doubt, I try to write [my lyrics] as I speak «. The choice of linguistic style is a vital element of a rapper's credibility. Language is used to manifest the links between music, identity and themes dealt with in the lyrics. In some cases the mixture of languages can reflect a shared attitude and a feeling of social belonging or of being an outsider, which supersedes linguistic borders. This is the case with the band Sveden Passive for example, whose songs describe suburban life, drug-positive opinions and anti-police sentiments in Finnish, Swedish and Sami. The use of several languages or codeswitching can also be a verbal demonstration of a tolerant multicultural ideology, as in Julkinen Sana's anti-racist »Mitä sä pelkäät?« (»What are you afraid of? «) and »Rakkaudella vihaajille« (»With love to the haters«), where the rappers self-ironically play with stereotypes surrounding their own identities.

In most cases the decision to make a record with Swedish, Finnish or English lyrics is based on personal, creative and aesthetic considerations, rather than merely straightforward semantic issues. In this sense, adopting sociolinguistic explanation models can lead us to overlook important aspects of multilingualism. For example, in literary studies on multilingualism, aesthetics, semantics and sociolinguistics are often understood to be intertwined. In Monika Schmitz-Emans' (2004: 11-16) classification for example, literature and multilingualism can refer to several adjacent and overlapping 
fields: the literature of multilingual nations or cultures, works by multicultural authors, multilingual texts, intermediality as multilingualism and multilingualism within one language. Following this approach, we can state that the Finland-Swedish context is already in a formal sense bilingual and most of the musicians can be considered multilingual, but the level and character of multilingualism or intermediality in their work is the result of deliberations concerning social and artistic self, image and personal voice.

Singing in standard Finland-Swedish might sound like a natural choice, but for those musicians who previously have been singing in, for example, English, it can be a radical change to start using Swedish. The use of one's mother tongue is often said to affect the use of voice and, in general, how the text is performed and what impression the singer makes. It can offer a more authentic expression, but at the same time it can feel too personal and revealing. As singer-songwriter Frida Andersson explains: "It is easier to write in English because Swedish is my emotional language, Swedish makes everything naked, direct; it hits you right in the face (Törnroos 2013).

The use of Finnish is often a natural alternative as this opens up many possibilities for developing a career in Finland and many of the Swedishspeaking musicians are anyhow more or less bilingual. It can also offer an opportunity to alternate between different aspects of a musician's personality. What exactly changes when the language changes can be hard to pinpoint. The alterations can be related to the many vowels and diphthongs used in Finnish, or the distinctive accentuation of Finnish, where the stress is on the first syllable. But it can also be expressively liberating, as actress/singer Jonna Järnefelt's account suggests: "Swedish is the language I learnt at home and school and it's connected to a good education, rules, being a good girl and achieving things; I believe I dare more in Finnish « (Lundin 2010). According to many sociologists and linguists, the social space of minority languages such as Swedish in Finland tend to become confined to the limits of the home and institutions that represent the linguistic establishment if the members of the minority do not use the language subsequently in all public contexts (e.g. Allardt 1997: 41f.; Tandefelt 2003: 189-191). As Järnefelt's example shows, from the personal perspective a majority language can be seen to offer new opportunities for the expression of a wider range of experiences than the minority language, if the minority language is only limited to formal or domestic fields of life.

The motivation for using English is often explained with reference to the notion that English »sounds right « or that it is the correct language for genres such as rock, jazz, or rap. This often comprises an idea of a common aesthetic ideal, which is tied to the Anglophone roots of these genres. As a 
result, performing these styles in English can offer opportunities for crossing sociolinguistic boundaries in a contemporary Finland-Swedish context. In some cases artists say that using Swedish or Finnish can be tricky as these languages are socially loaded, whereas English can offer them a neutral alternative. The hard rock singer Marco Luponero gives an account of how a switch from English to Swedish can instantly signify social belonging and the demarcation of cultural barriers when talking to the audience: »Once I used my Swedish dialect when presenting the next song but immediately somebody shouted >Fuck, speak Finnish<, so I switched back to English; it's safe« (Simosas 2009).

Choosing a language other than one's mother-tongue can also offer the singer a chance to take on a new role. For example, the singer-songwriter and jazz vocalist Nilla Hansson describes how she finds it appropriate to sing jazz in English as »it can be good to have some distance from the language « and performing in Finnish appeals because »it makes me another singer « (Hansson 2010). In the performance context the song can resemble a play, which carries meaning not just semantically, but through sounds that signify emotions and indicate character.

The careers and linguistic negotiation models of the Finland-Swedish musicians in the middle field between the core and the outer circle can be described as a kind of double identity, where the artist can vary his or her identification according to what seems fruitful for them at a given moment. This is by no means unique for the many forms of Swedishness in Finland. In fact, many Swedish speakers have always used Swedish and Finnish and lived in more than one culture while they have been conscious of the specific differences between both the languages and cultures and kept them separate. The multilinguistic dimension of popular music, combined with its symbolic connections to the urban and modern, often classified as »low culture, « have presumably contributed to keeping these individuals and cultural artistic expressions outside the core of the Finland-Swedish construction (for discussions on the dramatization of Finland-Swedishness, see Lönnqvist 2001a).

It is possible to say that many Swedish-speaking musicians have a bilingual, or perhaps even some form of a multilingual identity. Depending on what they deem to be functional in the current context, they can alternate between languages, depending on functionality. However, bilinguals are not necessarily equally fluent in all of their languages; switching between languages often serves a complementary distribution of variation according to the aim and context of the communication (for bilingualism see Romaine 1989: 18; Mackey 2000: 26f.). Within both the private and the public 
spheres there exists a flow of contacts, mobilities and linguistic identifications that are activated in different ways in different contexts. Certain languages and pronunciations seem to suit certain forms of musicking better than others. The flows across linguistic and ethnic boundaries do not mean that the boundaries will disappear. In fact, the construction of borders seems to form the very foundations on which embracing social systems are built (Barth 1969: 10). The linguistic choice is, in other words, an identificatory entity the contents of which are important for those who feel that they belong to a certain group, but these contents can be used in different ways depending on the situation; sometimes the signals are important and at other times unimportant.

\section{The Outer Circle: Developing a Career in Swedish, Finnish, or English}

The outer circle of my schematic presentation of the Finland-Swedish formation consists of the three major »others « of Finland-Swedishness: Finnish, Swedish and international cultures. The juxtaposition of FinlandSwedishness in relation to these three counterparts is crucial to the whole construction. However, it should be emphasized that just as the entire Finland-Swedish self-identification is in reality continuously changing, so is the position of these »others « and so are their particular implications for different Swedish-speaking Finns. For artists the natural starting point or goal may be to work primarily in Swedish in Sweden, in Finnish in Finland, or in English on an international market. In other words, they are functioning in the fields that in fact are major »others « when Finland-Swedish ethnicity is constructed. In this field their linguistic-ethnic background is often hidden, or it is neutralized as it has no relevance. In some cases the artists adapt their linguistic-ethnic background to suit the cultural expectations that the new audiences have of Finland-Swedishness. In such cases Finland-Swedishness becomes an »other « for these cultures.

As I mentioned earlier, these personal strategies in a way go against the dogmas of Finland-Swedish language politics, which are based on the idea that monolingual minority solutions are a key aspect in the preservation of the minority language. For the artists, these are nevertheless strategic choices that reflect their personal situations and ambitions.

For many Finland-Swedes, including musicians, working in or moving to Sweden is not a big step. For artists who have grown up on the west coast following Swedish music media, the linguistic step is particularly short. As 
one of these musicians, the dance band vocalist Hans Martin explains, to speak a standard form of Swedish as spoken in Sweden can feel like the most natural choice for public use, instead of using the very local dialect as used at home: $\gg \mid$ suppose my first >reak language [not dialect] was the Swedish language spoken in Sweden and it is very hard for me to speak anything else on stage « (Martin, interview 25.11.2007).

However, for other artists the differences between the standard Finland-Swedish language and the standard Swedish languages spoken in Sweden can include significant obstacles. Sometimes a Swedish record company has tried to iron out the Finland-Swedish accent. In some cases the Finland-Swedish artists have noticed that the Swedes do not even know that there is a Swedish-speaking minority in Finland and believe the singers are Finnish-speakers who have tried to learn proper Swedish. For example, the rapper Qruu has experienced: ^A Swede once said to me: >You have learnt Swedish bloody well, I can help you with the last bits « (Sandell 2011). On the other hand, for Swedes, Finland-Swedish can also sound exotic - or enchanting, as the Swedish pop artist Bo Kasper describes it: »beautiful, charming, meditative, and deep« (Ginström 2014).

Only a couple of bands have capitalized on the exoticism that FinlandSwedish pronunciation signifies on the international markets. Usually, their concept is based on references to Nordic mythology. For example, Gjallarhorn has been successful on the world music scene with their versions of Finland-Swedish medieval ballads and folk music. The heavy metal band Finntroll terms its style »trollmetal « and according to the band, FinlandSwedish singing is a key element of their »trollstyle «. In such cases FinlandSwedish pronunciation often signifies a general, pre-modern »otherness«, rather than a particular ethnicity for the listeners.

For those Finland-Swedes whose Finnish is weak, it can be an almost insurmountable task to create a career singing in Finnish although the record companies have tried to persuade the artists to do so. For example, the punk band Heartbreak Stereo was asked to start writing lyrics in Finnish when negotiating a record contract, but the band found the whole idea rather absurd both for stylistic and practical reasons: »For us it was like a joke to translate the lyrics to Finnish; we don't even know Finnish well enough « (Heartbreak Stereo, interview 12.1.2009).

Then again, for bilinguals whose Finnish is equally strong or maybe even stronger than Swedish, it may be a natural choice to use Finnish. The knowledge of a language is also related to its expressive value for the singer, as the pop singer Jannika B's explanation of her language choice suggests: »| came to the conclusion that the language I use when I quarrel is my emo- 
tionally strongest language and that's why I have used Finnish « (Lindholm 2013). One of the pioneers of Finnish rock lyricism, Dave Lindholm, has such a bilingual background and when, in the beginning of the 1970s, he changed from singing in English to singing in Finnish it was a way of finding a personal voice that felt natural: "When I started to write in the same way that I spoke, things started happening « (Holmberg 2010). In Dave Lindholm's case, »singing like talking « meant using Finnish in the form of traditional Helsinki slang, which contains elements of Swedish, Finnish and even some Russian from the beginning of the $20^{\text {th }}$ century. For the majority of the population he is still known as the key creator of Finnish rock lyricism and not many know about his Finland-Swedish background.

The Finland-Swedish audience can sometimes react with indignation when an artist uses Finnish, or the standard languages or dialects spoken in Sweden, as these choices can signify an abandonment of the Finland-Swedish identity. For the artist, language choice is a question of an appropriate adjustment to the personal, creative and social circumstances. Often this involves the basic tension of linguistic accommodation, in other words to »maximize fit and maintain distinctiveness « (Meyerhoff 2001: 67f.), so that the artist both converges with members of an in-group and diverges from linguistic out-groups in appropriate measures. What makes this so hard to accomplish is that the expectations of the commercial target group and the feeling of ethnic belonging do not necessarily run along the same lines. To use the concepts of communication accommodation theories, this can be explained as a complex attempt to adopt words, grammar, pronunciation, voice control, tempo and even body language in order to acquire a coveted social status without losing credibility (e.g. Einarsson 2004: 43f.). This type of accommodation is often welcomed by some, but it can also lead to negative responses if the accommodation is felt to be ingratiating, associated with suspect motives, or exaggerated, or when it is simply perceived of as a betrayal of a person's original group belonging (Bell 2006: 649).

A successful career in the major Finnish market, especially, can create a distance from the minority environment to the extent that the linguistic accommodation is understood to be an act of disloyalty. If artists who have created an image as performers of Finnish music with Finnish lyrics stick to their standard repertoire and language when performing in their Swedish home regions, the audience may greet their show with mistrust. Thus, for example Charles Plogman (interview 12.12.2008), who has made a successful career as a singer of Finnish schlager, has received much criticism for his style in his home region: "If you sing in Finnish in Ostrobothnia, they shake their fists at you. « This is a problem particularly when an artist has become 
famous for a personal repertoire and does not want to switch to, for example, cover versions.

In this respect English appears to be more neutral and its adoption a means of reconciling ethnic tensions. In popular music English is also a valued language. In sociolinguistic theory the appraisal of a language can be described as being based on the extent of the language's significance as an instrumental tool in career development, for example, as well as its communicative potential in different fields of social activity, its perceived identity value, and the prestige accorded by speakers and outsiders (Hene 1997: 137 and passim). In most instances English rates well in all of these values. English is the self-evident choice for most bands who try to achieve international success due to its importance both as a language of daily communication and as the main language of lyricism in this field. This is concisely summarized in the electro-pop ensemble Le Corps Mince de Francoise's comment reflecting upon their international success in relation to their language choice: »We wouldn't be here, if we hadn't used English« (Le Corps Mince de Francoise, interview 1.6.2009). As a result of tradition and genre conventions it is also a prestigious language, representing the norms and measures of success that the artists in many genres identify themselves with. In practice, the English lyrics are based on pithy catchphrases, which follow the conventions of the genre. Musicians have already learnt these genre rules at an early stage whilst listening to their international idols and writing lyrics in English in early adolescence. Therefore, they see English as their first language in this field of creative expression.

In the light of these examples, it seems that a large proportion of the musicians who somehow feel a connection to the formation »FinlandSwedishness «, along with its core elements, will actively reconstruct their identities during their careers. This process can also incorporate a contrast between the Finland-Swedishness, which is manifested in the core and a language policy that emphasizes monolinguistic minority solutions, and the daily life of the individual person (for a comparison with the tensions Irishspeaking musicians face in relation to the English language, see McCann/Ó Laoire 2003). Finland's Swedishnesses create a heterogeneity and flexibility which is typical of discourses such as this. At the same time, the public Finland-Swedish discourse can include demands for uniformity, which in turn can result in a feeling of marginality at the level of the individual (see e.g. Lönnqvist 2001b: 449f.). From a musician's point of view, the question concerns ultimately to what extent an individual can balance between being only an object, subordinate to the power of discourse and being a subject 
who can actually negotiate a position in relation to local demands and expectations.

\section{Conclusion}

To return to the question of my main heading "Why do songs have words in different languages? « an obvious answer would be: »Why not?« Just as musicians can choose between various stylistic features, cross genre borders, develop their artistic image and plan their careers during the course of their creative activities and personal development, so they can also make various language choices. These choices are not necessarily easy to make and have manifold consequences, but they can also give the artist opportunities to negotiate personal and social tensions.

In the Finland-Swedish context, language choice is a crucial question for an artist who wants to develop a professional career, but it also has significant consequences for amateurs as it determines the framework for communication, social networking and even stylistic features. It is not only the decision to use a particular language, which is important, but also the choice to combine and alternate languages, and of course the decision to avoid another language.

Language choice reflects the prevailing linguistic, ethnic and social structures and always exists in relation to language ideologies. The relationships between all these cultural issues are complex. Language choice is not only a matter of what language is used in a song and whether the lyrics are understood by the audience. It is also implicated in all situations of social interaction, including institutional contexts. However, it is never a straightforward choice of adopting an existing linguistic structure and ideology. As Berger (2003: xiv) has pointed out, »rather than merely reproducing existing ideologies, singers, culture workers, and listeners may use music to actively think about, debate or resist the ideologies at play in the social world around them «. A musician's creative work incorporates an opportunity to negotiate differing opinions and positions in such a way that the complexity of linguistic questions becomes a vital part of his or her artistry. This can be done by a playful or experimental approach to basic syntactic or morphological structures, by breaking phonetic or phonotextual conventions, or by combining the music with the speech melodies of various dialects and so on. The combination of music and language offers polysemic possibilities, which artists can use to express humorous, ironic, and ambiguous ideas. In a 
sense, language constructs meanings through wide-ranging associations that reach far beyond the level of semantics.

A creative use of language of course requires sensibility and an understanding of the context. Image and genre conventions are important when an artist's ethnic and social affiliations are evaluated, and the subtle balance between being accessible or distanced, or between convergent and divergent accommodation, can be hard to work out in practice. Also within one small linguistic community such as the Swedish-speaking minority of Finland the linguistic norms and values vary widely depending on the field of activities. State and commercial institutions, high, folk and popular cultural forms, different genres and so on, all have different norms. At the level of the individual, we are talking about processes where an artist negotiates his or her multiple identities. These identities are partly linguistic identities, as most people and social environments are at least to some extent bilingual, but they are also professional and social identities, which interact in complex ways. At the level of society, language choice is connected to language ideologies, but these are not necessarily a one-dimensional force binding together the speakers of a language. We can speak about multiple ideologies that describe the same phenomenon from different angles and offer different solutions to daily problems. As such, the multiple ideologies offer differing interpretive and experiential positions with regard to language choice and use. And it is within this field of multiple identities and multiple language ideologies that the musicians, thanks to the creative potential offered by art, can both stabilize and critically study the varying cultural positions present in the society.

\section{Bibliography}

Allardt, Erik (1997). Vårt land, vårt språk. Kahden kielen kansa. En attitydundersökning om det svenska i Finland. Suomalaisia asenteita ruotsin kieleen Suomessa. Helsingfors: Svenska Finlands folkting.

Allardt, Erik / Starck, Christian (1981). Språkgränser och samhällsstruktur. Finlandssvenskarna i jämförande perspektiv. Stockholm: Almqvist \& Wiksell.

Åström, Anna-Maria / Lindqvist, Yrsa / Lönnqvist, Bo (eds.) (2001). Gränsfolketsbarn. Finlandssvensk marginalitet och självhävdelse kulturanalytiskt perspektiv. Helsingfors: Svenska litteratursällskapet i Finland.

Barth, Fredrik (1969). »Introduction. «In: Ethnic Groups and Boundaries. The Social Organization of Cultural Difference. Ed by Fredrik Barth. Oslo: Universitetsforlaget, pp. 9-38. 
Bell, Allan (2006). »Speech Accommodation Theory and Audience Design. «In: Encyclopedia of Language \& Linguistics. Amsterdam: Elsevier Science (2nd edition), pp. 648-651.

Berger, Harris M. (2003). »Introduction. «In: Global Pop, Local Language. Ed. by Harris M. Berger and Michael Thomas Carroll. Jackson, MS: University Press of Mississippi, pp. ix-xxvi.

Berger, Harris M. / Carroll, Michael Thomas (ed.) (2003). Global Pop, Local Language. Jackson, MS: University Press of Mississippi.

Brusila, Johannes (2008). »Den finlandssvenska populärmusikens vara eller inte vara -diskursiva och nymaterialistiska utgångspunkter för etnicitetsinriktad musikforskning. «In: Etnomusikologian vuosikirja 20. Helsinki: Suomen etnomusikologinen seura, pp. 301-321.

Brusila, Johannes (2009). »Between Minor and Major. Discursive and Neomaterialist Reflections on Lasse Mårtenson and >Finland-Swedish Popular Music. «In: Voices of the Weak: Music and Minorities. Ed. by Zuzana Jurková and Lee Bidgood. Praha: NGO Slovo21 \& Faculty of Humanities of Charles University, pp. 34-58.

Brusila, Johannes (2010). »>Maximum Output for Minimum Input.< 1G3B and the Reterritorialization of a Finland-Swedish Metal Identity on the Internet. « In: IASPM@Journal 1:2, http://www.iaspmjournal.net/index.php/IASPM_Journal/ article/view/541 (accessed July 18, 2015).

Brusila, Johannes (forthcoming). »Durmusikens förvaltare och mollmurens vältare. Dansbandsmusiken som av- och återterritorialiserare av Svenskfinland.« In: Modersmålets sånger. Finlands svenskheter framställda genom musik. Ed. by Johannes Brusila, Pirkko Moisala and Hanna Väätäinen, Helsingfors: Svenska litteratursällskapet i Finland.

Burr, Vivien (1995). An Introduction to Social Constructionism. London: Routledge.

Einarsson, Jan (2004). Språksociologi. Lund: Studentlitteratur.

Feld, Steven / Fox, Aaron A. (1994). »Music and Language. «In: Annual Review of Anthropology 23, pp. 25-53.

Frith, Simon (1987). »Why Do Songs Have Words?« In: Lost in Music: Culture, Style and the Musical Event. Ed. by Avron Levine White. London: Routledge \& Kegan Paul, pp. 77-106.

Hall, Stuart (1992). »The Question of Cultural Identity.«In: Modernity and its Futures. Ed. by Stuart Hall, David Held and Tony McGrew. Cambridge: Polity Press \& Open University, pp. 273-316.

Hall, Stuart (1996). »Introduction: Who Needs >Identity «? In: Questions of Cultural Identity. Ed. by Stuart Hall and Paul du Gay. London: Sage Publications, pp. $1-17$.

Hene, Birgitta (1997). »Ett språks värde. « In: Svenska som andraspråk och andra språk. Festskrift till Gunnar Tingbjörn. Ed. by Anders-Börje Andersson. Göteborg: Institutionen för svenska språket, Göteborgs universitet, pp. 135-151.

Larkey, Edward (2000). "Just for fun? Language choice in German popular music.« In: Popular Music and Society 24: 3, pp. 1-20.

Lilliestam, Lars (1998). Svensk rock. Musik, lyrik, historik. Göteborg: Bo Ejeby förlag.

Lindberg, Ulf (1995). Rockens text. Ord, musik och mening. Stockholm, Stehag: Brutus Östlings bokförlag Symposion.

Loman, Bengt (1983). »Perspektiv på Bergroth.«In: Svenskt i Finland 1. Ed. by Max Engman and Henrik Stenius. Helsingfors: Svenska litteratursällskapet i Finland, pp. 71-97. 
Lönnqvist, Bo (2001a). "Symboler och etnisk dramatisering. «In: Gränsfolket barn. Ed. by Anna-Maria Åström, Bo Lönnqvist and Yrsa Lindqvist. Helsingfors: Svenska Litteratursällskapet i Finland, pp. 223-225.

Lönnqvist, Bo (2001b). »Diskursen oh det oartikulerade varandet. Ett ifrågasättande av identitetskonstruktionen. «In: Gränsfolket barn. Ed. by Anna-Maria Åström, Bo Lönnqvist and Yrsa Lindqvist. Helsingfors: Svenska Litteratursällskapet i Finland, pp. 443-450.

Mackey, William F. (2000). »The Description of Bilingualism. In: The Bilingualism Reader. Ed. by Li Wei. London, New York: Routledge, pp. 26-54.

McCann, Anthony / Ó Laoire, Lillis (2003). » Raising One Higher than the Other.< The Hierarchy of Tradition in Representations of Gaelic- and English-Language Song in Ireland. «In: Global Pop, Local Language. Ed. by Harris M. Berger and Michael Thomas Carroll. Jackson, MS: University Press of Mississippi, pp. 233-265.

Meyerhoff, Miriam (2001). $\gg$ Dynamics of Differentiation: On Social Psychology and Cases of Language Variation. «In: Sociolinguistics and Social Theory. Ed. by Nicolas Coupland, Srikant Sarangi and Cristopher N. Cadlin. Harlow: Longman, pp. 61-87.

Romaine, Suzanne (1989). Bilingualism. Oxford: Basil Blackwell.

Schmitz-Emans, Monika (ed.) (2004). "Literatur und Vielsprachigkeit. Aspekte, Themen, Voraussetzungen. «In: Literatur und Vielsprachigkeit (= Hermeia. Grenzüberschreitende Studien zur Literatur- und Kulturwissenschaft 7). Heidelberg: Synchron, pp. 11-26.

Small, Christopher (1997). Musicking, The Meanings of Performing and Listening. Hanover, NH: University of New England.

Tandefelt, Marika (2003). Tänk om ... Svenska språknämndens förslag till handlingsprogram för svenskan i Finland. Helsingfors: Forskningscentralen för de inhemska språken.

Trudgill, Peter (1983). On Dialect. Social and Geographical Perspectives. Oxford: Basil Blackwell.

Wei, Li (2000). »Dimensions of bilingualism.«The Bilingualism Reader. Ed. by Li Wei. London, New York: Routledge, pp. 3-25.

\section{Interviews}

(Translations from Swedish to English by Johannes Brusila)

Plogman, Charles (12.12.2008). Interviewer Johannes Brusila.

Heartbreak Stereo (12.1.2009). Interview with members of Heartbreak Stereo: Alfred Kullberg and Robin Reuter. Interviewer Johannes Brusila.

Le Corps Mince de Francoise (1.6.2009). Interview with the members of Le Corps Mince de Francoise: Emma Kemppainen, Mia Kemppainen and Malin Nyqvist. Interviewer Johannes Brusila.

Lindqvist, Jan-Erik (13.3.2007). Interviewer Johannes Brusila.

Martin, Hans (25.11.2007). Interviewer Johannes Brusila.

Nörttibois Crew (15.12.2008). Interview with members of Nörttibois Crew: Mikael »Dt1 « Hästö and Elias »Elias L. « Levo. Interviewer Johannes Brusila.

Pappas eget band (13.11.2009) Interview with the members of Pappas eget band: Niklas Rosström and Niklas Nylund. Interviewer Johannes Brusila.

Qruu (Johan Kvarnström) (4.3.2009). Interviewer Johannes Brusila 


\section{Radio programmes \\ (Translations from Swedish to English by Johannes Brusila)}

Ginström, Gunilla (2014). Vega Visor. Interviewee: Bo Sundström (Bo Kaspers orkester). Radio Vega, Finnish Broadcasting Company, broadcast 1.9.2014.

Granö, Viktor (2014). Dokumenterat: Vem är Häxjesus. Interviewee: Akse Pettersson. Radio Vega, Finnish Broadcasting Company, broadcast 31.4.2014.

Hagström, Marcus (2005). Egocentrum. Interviewees: Marcus »Hagge « Hagström and Pia Manns of Paradisbacka. Radio Vega, Finnish Broadcasting Company, broadcast 18.12.2005.

Hansson, Nilla (2010). Åboländsk music. Interviewee: Nilla Hansson. Radio Vega Åboland, Finnish Broadcasting Company, broadcast 20.9.2010.

Holmberg, Ole (2010) Fokus på Dave Lindholm. Interviewee: Dave Lindholm. Radio Vega, Finnish Broadcasting Company, 26.1.2010.

Lindholm, Frida (2013). Hon som inte rådnar med Jannika B. Interviewee: Jannika B. Yle X3M, Finnish Broadcasting Company, broadcast 23.8.2013.

Lundin, Thomas (2010). Allt ljus på Jonna Järnefelt. Interviewee: Jonna Järnefelt. Radio Vega, Finnish Broadcasting Company, broadcast 28.6.2010.

Sandell, Ralf (2011). Kulturtimmen. Interviewee: Qruu. Radio Vega, Finnish Broadcasting Company, broadcast 4.8.2011.

Simosas, Kjell (2009). Metallrepubliken. Interviewee: Marco Luponero. Radio Extrem, Finnish Broadcasting Company, broadcast 24.8.2009.

Törnroos, Benny (2011). Du sköna sång, del 37. Interviewee: Lasse Eriksson. Radio Vega, Finnish Broadcasting Company, broadcast 3.7.2011.

Törnroos, Benny (2013). Fonden. Interviewee: Frida Andersson. Radio Vega, Finnish Broadcasting Company, broadcast 2.12.2013.

Törnroos, Benny (2015). Fonden, Spelmannen, jazzdiggaren, visvännen och radiomannen Åke Grandell. Del 2. Interviewee: Åke Grandell. Radio Vega, Finnish Broadcasting Company, broadcast 9.3.2015.

Willows, Elin (2012). Kulturtimmen: Vasas flora och fauna. Interviewees: Mattias Björkas and liris Viljanen of Vasas flora och fauna. Radio Vega, Finnish Broadcasting Company, broadcast 15.5.2012.

\section{Discography}

Julkinen Sana \& Ricky-Tick Big Band (2013). »Mitä sä pelkäät. « On: Burnaa. Rokka (Sony) 88883712602.

Julkinen Sana \& Ricky-Tick Big Band (2013). »Rakkaudella vihaajille. On: Burnaa. Rokka (Sony) 88883712602. 


\begin{abstract}
This article takes as its starting point the idea that a musician's choice of which language to use in song lyrics is an important but often neglected field of study. Even small linguistic nuances can signify ethnic, social, or aesthetic positions and have consequences for the structure of the music, its industrial dissemination and potential, and how it is received and understood. The aim is to study what factors motivate artists in the choices they make and how their choices relate to their sociolinguistic and cultural contexts, musical framework and construction of identity. Based on a study of musicians who belong to the Swedish-speaking minority of Finland, the so-called »Finland-Swedes «, the article claims that language choice is never a straightforward choice of adopting an existing linguistic structure and ideology. A musician's creative work incorporates an opportunity to negotiate differing opinions and positions in such a way that the complexity of linguistic questions becomes a vital part of his or her artistry.
\end{abstract}

